\title{
Demographic Change and Bank Profitability. Empirical Evidence from German Savings Banks
}

\author{
Michael Berlemann \\ Marco Oestmann \\ Marcel Thum
}

CESIFO WORKING PAPER NO. 2911

CATEGORY 11: INDUSTRIAL ORGANISATION

JANUARY 2010
An electronic version of the paper may be downloaded
- from the SSRN website:
www.SSRN.com
- from the RePEc website:
- from the CESifo website:
www.RePEc.org
www.CESifo-group.org/wp




\title{
Demographic Change and Bank Profitability. Empirical Evidence from German Savings Banks
}

\begin{abstract}
Most European economies will experience significant demographic changes in the decades ahead. Due to low birth rates, populations are shrinking and ageing at the same time. This paper explores the impact of demographic change on the banking industry. A unique data set, which contains detailed information on almost 2.5 million accounts in 11 German savings banks, allows us estimating the socio-demographic determinants of retail profitability. Using a simulation model, we are able to predict the development of bank profitability due to demographic shifts up to 2025. One of the main findings is that the effects of population ageing will partially offset the impact of shrinking customer bases. While the decline in the size of the population reduces the customer base, ageing per se increases profitability as older customers typically generate higher profits for their banks.
\end{abstract}

JEL-Code: G21, J10, L10, O16.

Keywords: demography, banking, savings banks, profitability.

Michael Berlemann

Helmut-Schmidt-University Hamburg Institute for Theoretical Economics

Postbox 700822

Germany - 22008 Hamburg

berlem@hsu-hh.de
Marco Oestmann

Hamburg Institute of International Economics (HWWI)

Heimhuder Straße 71

Germany - 20148 Hamburg

oestmann@hwwi.org

Marcel Thum

Dresden University of Technology and

Ifo Institute of Economics Research, Dresden Branch

Department of Economics

Germany - 01062 Dresden

marcel.thum@tu-dresden.de

January 10, 2010 


\section{Introduction}

Retail banking is mostly a non-traded good as many customers demand services from a local branch. Such business in non-traded goods is very sensitive to changes in the size and composition of the local customer base. For a long time, the highly industrialized western economies have experienced a growing or constant population. Therefore, the strategies of banks aimed mostly at gaining customers in a growing market. Demographic change with shrinking and ageing customers has changed the perspective. Banks have started to experience a competition for a a shrinking local population, which can be a serious threat to the profitability of retail banking. This paper explores the consequences of demographic change on bank profitability.

For most European countries, demographic change does not only imply a decrease in the population size but also an ageing population. According to UN projections [United Nations (2007)], the countries in central and eastern Europe will experience the most rapid population loss. Bulgaria and Ukraine are the forerunners in this process and will have lost around $2.4 \%$ of their 2005 populations by the year $2020 .{ }^{1}$ In southern and western Europe, the more significant demographic process will be ageing. Germany's population, will only shrink by $0.12 \%$ by 2020 . The median age, however, is projected to increase by as much as 5.2 years from 42.1 years in 2005 to 47.3 years in 2020 . Then only Italy is projected to have an even older population with a median age of 47.5 years.

The view on national aggregates masks the large heterogeneity within countries. Even though the population decline in Germany as a whole is only of minor importance up to 2020 , there are large variations in regional population trends. While the western German population remains roughly constant up to 2020, eastern Germany will loose $8 \%$ of its 2005 population - with some municipalities loosing more than $20 \%$. The large heterogeneity in demographic developments makes Germany a suitable laboratory example for studying the consequences of demographic change.

\footnotetext{
1 All values pertain to the medium variant of the 2006 revision of the World Population Prospects Database by the Population Division of the Department of Economic and Social Affairs of the United Nations Secretariat, accessible at: http://esa.un.org/unpp.
} 
The shifts in the size and age structure can have significant consequences for the economy as a whole. So far, the economics literature has mostly focused on the macroeconomic impact of demographic changes. In particular, the impact on public pension schemes [e.g., Casamatta et al. (2001), Demange and Laroque (1999), Fehr (2000)], on inflation [Lindh and Malmberg $(1998,2000)]$, on labour markets [e.g. Boersch-Supan (2003), Henschel et al. (2008)], on publicly provided goods [e.g., Borge and Ratts $\varnothing$ (2008), Cattaneo and Wolter (2009), Montén and Thum (2009)] and on capital markets [e.g., Abel (2001), Boersch-Supan et al. (2002), Krueger and Ludwig (2007), Miles (1999), Poterba (2001, 2004)] has been extensively studied. For instance, the entire financial market may be affected by demographic change, when the elderly try to withdraw their accumulated savings without having a sufficiently large young population that is willing to hold those assets. Demographic transitions may change the capital stock and/or the returns of an economy.

In contrast to the extensive macroeconomic analysis, very little is known about the microeconomic consequences of demographic change. There is some debate on age-dependent productivities [e.g., Daveri and Maliranta (2007) and Skirbekk (2003)] and the appropriate age composition of the workforce when skills differ between age groups [Grund and Westergard-Nielsen (2008)]. Beyond human resources, however, very little research has been conducted on the demographic challenges for firms and on how these firms should react. In particular, one would expect that the decline in population size leads to a shrinking demand in the retail business of non-traded-goods. A naive forecast would suggest that the decline in the population size leads to a proportional decline in retail business. This is the starting point for our analysis of the banking industry. As it turns out, retail business depends on a more complex interaction between the decline in population size and the ageing of a society.

We analyze the impact of demographic change on retail banking - an excellent example for the business with non-traded goods. On the one hand, a decline in the population size poses a threat to the customer base. ${ }^{2}$ On the other hand, the parallel process of ageing may

\footnotetext{
${ }^{2}$ See Neuberger (2008) for an investigation of bank managers' awareness of demographic change.
} 
compensate for the loss in customers for at least two reasons. Firstly, older customers are wealthier. Moreover, they are less flexible and thus less willing to switch bank accounts. Both effects point in the direction of higher bank profits.

We exploit a novel and unique dataset of more than 2.4 million private bank accounts with German savings banks. The dataset allows us to run a regression on the determinants of individual profit contributions. We find a customer's age to have a direct and an indirect effect (via age-specific portfolios) on bank profits. Using the regression parameters and a demographic projection, we then build a simulation model of bank profitability up to 2025. In this simulation model, profitability is driven by the interaction of demographic change and the determinants of bank profitability.

In summary, the negative effects of the shrinking population on retail business are largely dominated by positive effects of the ageing of society. While the German population shrinks by $-1.8 \%$ over the projection horizon, the customer base will only shrink by some $0.2 \%$. Including the ageing effects, we find that the profits of German savings banks will grow by almost $9 \%$ up to 2025 . Thus, the pure demographic effect on the retail business of German savings banks is likely to be positive. However, when taking into account the increasing competition in the banking sector and an increasing price sensitivity, especially of elderly bank customers, the projections in general become much less optimistic. In a realistic scenario of demographic change and increased banking competition we estimate a loss of 3 percent in profits.

In Section 2, we explain our empirical approach. Section 3 contains a description of the demographic data and the bank customer data. In Section 4, we present our baseline projection of retail profits for German savings banks. The baseline scenario tries to capture the pure demographic effect. Then we modify the scenarios in order to receive a more realistic development in retail banking. Section 5 takes into account that, due to increased competition, the historically large market shares of savings banks among adult customers will decline in the future. In addition, Section 6 corrects for the currently high profits from elderly customers; growing financial sophistication and knowledge among elderly customers will most likely drive down retail profits from this group. Section 7 concludes. 


\section{Empirical approach}

Many countries around the world are facing decreasing and aging populations. Our aim is to study whether and how this demographic challenge will influence the profitability of private banking in these countries. We focus on the example of German savings banks. Germany is a excellent laboratory for studying the likely consequences of demographic change for two reasons. First, Germany has a well developed financial system. Second, the expected demographic change is substantial. The latter is especially true for eastern Germany where the population is expected to decrease considerably and quickly. We focus on savings banks as these banks have large market shares in private banking (especially in eastern Germany). Moreover, savings banks cover the whole range of bank customers from poor to rich. ${ }^{3}$

We proceed in three steps to analyze the impact of demography on bank profitability. In a first step, we identify customer-related determinants of bank profitability. We make use of individual customer data provided by 11 German savings banks, operating in different regions in eastern and western Germany. The data set covers 2.4 million accounts and refers to the year 2006. Besides information on the customers' assets, liabilities, income and various socio-demographic characteristics, the dataset also contains information on the profit contribution each customer generates for his bank. ${ }^{4}$ Using the cross-section regression technique, we then identify significant determinants of individual profit contributions.

To forecast savings banks' profitability up to 2025, it is necessary to make projections of the likely development of the number and the age structure of bank customers. In a second step, we therefore evaluate the market exploitation of the banks in their

\footnotetext{
${ }^{3}$ German banking is characterized by the coexistence of three types of banks - commercial banks, cooperatives and public sector banks. First, commercial banks are corporations and operate as universal banks. Second, cooperative banks are characterized by a special governance structure where the equity holders - usually customers of the cooperative banks - have equal voting rights independent of their equity shares. Third, German banking also comprises a large sector of state-owned banks. The savings banks are an important pillar of the state-owned banks. The savings banks operate locally or regionally and they are owned by their respective municipalities or counties. Overall, the savings banks account for 13.8 percent of banking assets in Germany. For a comprehensive survey of the German banking system, see Brunner et al. (2004) and Krahnen and Schmidt (2004).

4 A more detailed description of the data can be found in section 3.1.
} 
business regions for every single age class. While the banks in our sample are located in different regions, they cover only a fraction of all German regions. We have to assume that market exploitations of our sample banks are representative for all German regions. Since savings banks in eastern Germany have considerably higher market exploitations than their western German counterparts, we calculate market exploitations separately for eastern and western Germany for the year 2006. To obtain the future size of the customer base, we apply the calculated market exploitation rates to the demographic projections of the Federal Institute for Research on Building, Urban Affairs and Spatial Development (BBSR). ${ }^{5}$ Thus, we end up with a projection of the number of savings banks' customers (and their ages) for every German NUTS II region.

In the third step, we use our data to construct the typical portfolio of a bank customer for every single age class. Using the estimation results from step one we can then calculate the expected profit contribution for every single customer. Summing up for all customers of a certain region allows to predict how demography will affect profits from private banking in these regions.

\section{Data}

Our study employs two sets of data. Besides the banking data on the individual customer level, we also need demographic projections for the German regions. Before turning to the empirical analysis and the projections of bank profitability, we give an overview on the employed data.

\footnotetext{
5 This procedure implies that market exploitation of savings banks remains constant over the projection period. While this assumption might be realistic for western Germany it is quite optimistic for eastern German savings banks (see sections 5 and 6). We therefore also study alternative scenarios of market exploitation. For a more detailed description of the demographic projections see section 3.2 .
} 


\subsection{BANK DATA}

\section{Variables}

Our banking dataset consists of customer data from 11 German savings banks. ${ }^{6}$ Eight of these banks are located in eastern Germany, three banks operate in western Germany. Three banks are primarily engaged in larger cities, the remaining banks serve rural regions and smaller cities.

For every bank included in our sample, we have a complete record of all private customer accounts. ${ }^{7}$ While the vast majority of private customer accounts in our sample are individual accounts, there is a significant number of joint accounts, typically owned by (married) couples. Since we need the data on an individual basis, we decided to split up joint accounts by assigning the assets and liabilities proportionally to (fictitious) individual accounts.

Table I. Description of variables

\begin{tabular}{|c|c|c|}
\hline Variable & Description & Values \\
\hline prof & customer's profit contribution & $\begin{array}{l}\text { gross profit contribution II of a customer in } \\
\text { reference year }(€)\end{array}$ \\
\hline giro & customer holds a giro account & no $=0$, yes $=1$ \\
\hline sex & sex of customer & male $=0$, female $=1$ \\
\hline west & affiliation of customer & $\begin{array}{l}\text { customer belongs to a west german bank }=1 \text {, } \\
\text { customer belongs to a east german bank }=0\end{array}$ \\
\hline $\operatorname{age}(\mathrm{m})$ & age of customer at reference date & $\begin{array}{l}\text { if customer has age } \mathrm{m} \text {, then age }(\mathrm{m})=1 \text {, } \\
\text { otherwise } \operatorname{age}(\mathrm{m})=0 ;(\mathrm{m}=0,1, \ldots, 85+)\end{array}$ \\
\hline inc & average monthly income of customer & average value in reference year $(€)$ \\
\hline cred & utilized credit line (giro account) & value at end of reference period $(€)$ \\
\hline loan & loans & value at end of reference period $(€)$ \\
\hline sight & sight deposits & value at end of reference period $(€)$ \\
\hline time & time deposits & value at end of reference period $(€)$ \\
\hline secex & $\begin{array}{l}\text { securities issued by external institu- } \\
\text { tions }\end{array}$ & value at end of reference period $(€)$ \\
\hline secin & $\begin{array}{l}\text { securities issued by the German savings } \\
\text { bank fund }\end{array}$ & value at end of reference period $(€)$ \\
\hline sav & savings deposits & value at end of reference period $(€)$ \\
\hline
\end{tabular}

\footnotetext{
${ }^{6}$ Due to confidentiality requirements, we are not allowed to reveal information on the name of the banks included in the sample.

7 Corporate clients holding accounts were excluded from the sample, since these accounts are much less dependent on demography than the accounts of private clients.
} 
Table I gives an overview on the variables which are available for every bank customer. The table also provides a brief description of the variables. All variables refering to stocks (loans, utilized credit-line, sight-deposits, time-deposits, savings-deposits, securities issued by external institutions, securities issued by bank) were recorded with their values as of December 31st, 2006. The available dummy variables (sex, giro-account-holder, age) also refer to this date. For the age of the customers, we defined 86 dummy variables age $(m)$ with $m=0,1, \ldots 84,85+$. The two remaining variables (income and profit contribution) have the character of flows. The incomevariable is measured as the average monthly income over the year 2006. A customer's profit contribution is the cumulated value over the year $2006 .^{8}$

\section{Descriptive statistics}

Some observations had to be excluded from the sample. First, we excluded all observations of customers having neither assets nor liabilities with the savings bank (56.383 observations). While these customers are in the books of their savings bank, the bank has no active business with them. Thus, they actually do not contribute to the profits of the bank and, therefore, should be neglected for the purpose of this study. Secondly, we excluded all observations which are likely to be misreported. For example, we deleted customers with unknown age or with a reported age of more than 100 years from the sample $(38.030$ observations). ${ }^{9}$ Moreover, some observations were dropped because of highly implausible values for asset, liability or income variables (13 observations).

Ultimately, our sample consists of 2.472 .485 customers of 11 German savings banks. While 1.923.154 observations come from the 8 eastern German savings banks, the remaining 549.331 observations are from western Germany. Table II provides the summary statistics for our variables.

\footnotetext{
8 Three banks in our sample were only able to deliver data for 2007. Due to the short time span in between the recording dates, the possible error should be negligible. All qualitative results remain unaffected by including these banks.

9 While a small number of customers might in fact be older than 100 years, the data most likely refer to deceased customers, which have not yet been deleted from the databases.
} 
Table II. Descriptive statistics

\begin{tabular}{|c|c|c|c|c|c|c|}
\hline \multirow{2}{*}{ variable } & \multicolumn{2}{|c|}{$\begin{array}{l}\text { Western Germany } \\
\mathrm{n}=549331\end{array}$} & \multicolumn{2}{|c|}{$\begin{array}{l}\text { Eastern Germany } \\
\mathrm{n}=1923154\end{array}$} & \multicolumn{2}{|c|}{$\begin{array}{l}\text { Germany } \\
\mathrm{n}=2472485\end{array}$} \\
\hline & mean & $\begin{array}{l}\text { standard } \\
\text { deviation }\end{array}$ & mean & $\begin{array}{l}\text { standard } \\
\text { deviation }\end{array}$ & mean & $\begin{array}{l}\text { standard } \\
\text { deviation }\end{array}$ \\
\hline prof & 291.92 & 811.35 & 257.94 & 421.28 & 265.49 & 533.39 \\
\hline giro & 0.7065 & 0.4554 & 0.8094 & 0.3928 & 0.7865 & 0.4098 \\
\hline sex & 0.5103 & 0.4999 & 0.5362 & 0.4987 & 0.5304 & 0.4991 \\
\hline west & - & - & - & - & 0.2222 & 0.4157 \\
\hline inc & 700.89 & 3372.04 & 852.80 & 1031.85 & 819.05 & 1832.61 \\
\hline cred & 256.64 & 6166.37 & 80.85 & 1061.46 & 119.91 & 3054.47 \\
\hline loan & 6520.07 & 44955.61 & 1435.38 & 11414.95 & 2565.09 & 23555.06 \\
\hline sight & 2078.72 & 14993.30 & 2391.31 & 8282.43 & 2321.86 & 10164.63 \\
\hline time & 1135.08 & 32975.54 & 51.71 & 2219.66 & 292.41 & 15672.51 \\
\hline secex & 3371.32 & 63941.88 & 977.48 & 7410.68 & 1509.34 & 30856.01 \\
\hline secin & 1050.50 & 9954.41 & 1178.32 & 5922.73 & 1149.92 & 7021.64 \\
\hline sav & 5169.25 & 24994.07 & 6182.71 & 14893.22 & 5957.54 & 17649.35 \\
\hline & & & total & & & \\
\hline assets & 6776.70 & 46174.65 & 1516.23 & 11502.37 & 2684.99 & 24112.15 \\
\hline liabilities & 12804.86 & 86254.27 & 10781.54 & 22827.80 & 11231.07 & 45376.12 \\
\hline
\end{tabular}

\subsection{Demographic ProjeCtions}

We employ the projections ("Raumordnungsprognose 2025") provided by the Federal Institute for Research on Building, Urban Affairs and Spatial Development (BBSR). This projection is closely linked to those of the German Federal Statistical Office but has the advantage that it is available for every single year and age class on the NUTS II level. According to the BBSR projection, Germany will loose $1.8 \%$ of its population in the period of 2006 to 2025 . While western Germany is expected to gain some $0.4 \%$ up to 2025, the eastern German population will decrease by almost $14 \%$. As it is shown in figure 1, there is a great deal of diversity among the German NUTS II regions. Most eastern German regions are expected to shrink in terms of population, some of them (Chemnitz: $-17.5 \%$, Thuringia: $-15.9 \%$, Mecklenburg-Pomerania: $-15.4 \%$ ) by rates of more than $15 \%$. In western Germany, the projected development is much less severe. While some western German NUTS II regions will also loose a considerable part of their population (for example Saarland: $-7.8 \%$, Braunschweig: $-7.1 \%$ or Upper Franconia: $-7.0 \%$ ), most 


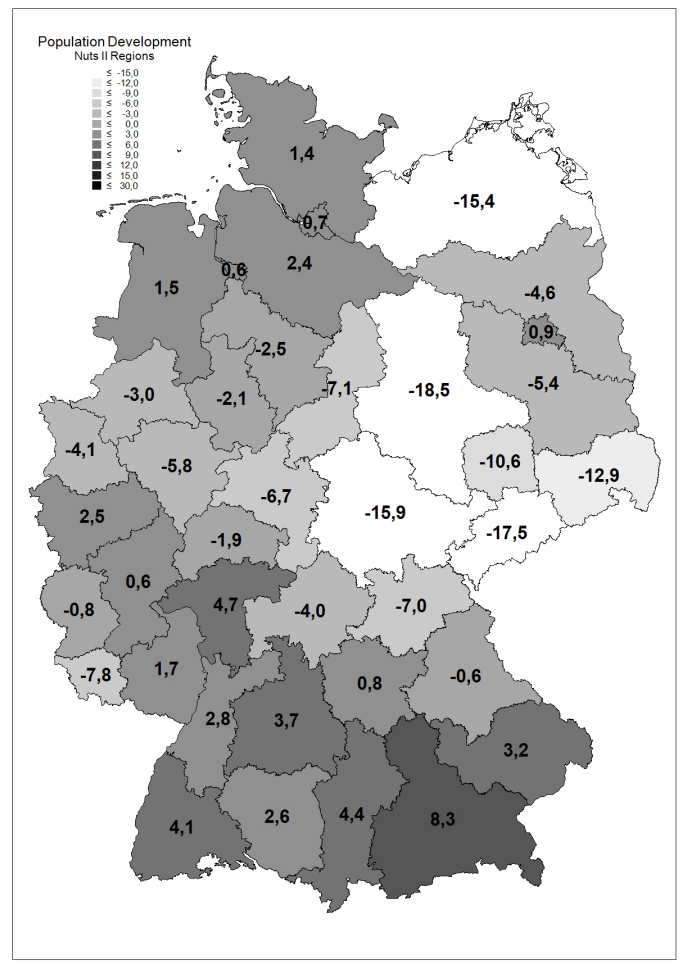

Figure 1. Changes in population size in German NUTS II regions, 2006-2025 [Source: BBSR (2009)]

regions like Luneburg $(+2.4 \%)$ or Bremen $(+0.6 \%)$ are likely to experience moderate population gains. The highest growth rate can be observed in Upper Bavaria (8.3\%).

Besides the effects on population size, eastern as well as western German regions are also subject to severe ageing effects. As figure 2 shows, the average age increases significantly in both parts of Germany, although this pattern is again more pronounced in eastern Germany The average age increases by 3.4 and 5.7 years in western and eastern Germany, respectively. 


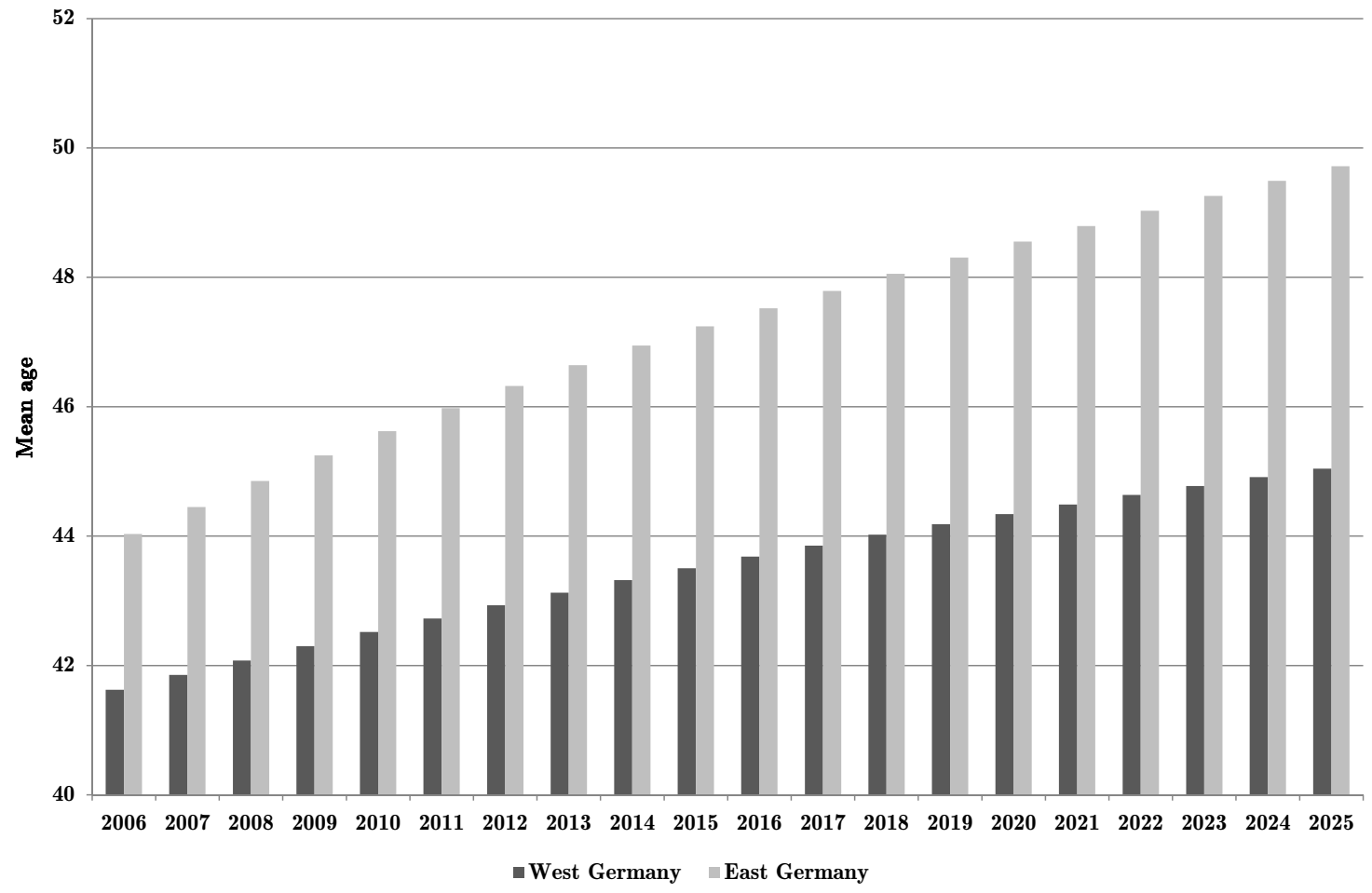

Figure 2. Ageing of German population, 2006-2025 [Source: BBSR (2009)]

\section{Pure demography and the retail profits of German savings banks}

\subsection{Determinants of Customers' Profit COntributions}

In the first step of our analysis, we identify the individual determinants of customers' profit contributions. We regress customers' profit contributions on their individual characteristics. Thus, we estimate the following equation using OLS and White-corrected standard errors. ${ }^{10}$

\footnotetext{
10 Note that all correlation coefficients between the regressors were sufficiently small to rule out any multicollinearity problems. The correlation matrix is shown in the appendix.
} 


$$
\begin{aligned}
\text { prof }_{i}= & \alpha_{0}+\alpha_{1} \cdot \text { giro }_{i}+\alpha_{2} \cdot \text { sex }_{i}+\alpha_{3} \cdot \text { west }_{i}+\alpha_{4} \cdot \text { inc }_{i}+\alpha_{5} \cdot \text { cred }_{i} \\
& +\alpha_{6} \cdot \operatorname{loan}_{i}+\alpha_{7} \cdot \operatorname{sight}_{i}+\alpha_{8} \cdot \text { time }_{i}+\alpha_{9} \cdot \text { secex }_{i}+\alpha_{10} \cdot \operatorname{secin}_{i} \\
& +\alpha_{11} \cdot \operatorname{sav}_{i}+\sum_{m=1}^{85+} \beta_{m} \cdot \operatorname{age}(m)_{i}+\epsilon_{i}
\end{aligned}
$$

The estimation results are shown in table III. ${ }^{11}$

Table III. Estimation results determinants of profit contributions

\begin{tabular}{lllr}
\hline variable & coefficient & $\begin{array}{l}\text { robust } \\
\text { standard } \\
\text { error }\end{array}$ & t-value \\
\hline cons & $-7.067868^{* * *}$ & 1.418876 & -4.98 \\
giro & $126.8462^{* * *}$ & 9.687804 & 13.09 \\
sex & 1.064344 & 2.726524 & 0.39 \\
west & $12.36327^{* * *}$ & 2.856060 & 4.33 \\
inc & -0.0013874 & 0.007949 & -0.17 \\
& & & 5.06 \\
cred & $0.0126553^{* * *}$ & 0.0025 & 30.82 \\
loan & $0.0097013^{* * *}$ & 0.0003147 & 5.30 \\
sight & $0.0107212^{* * *}$ & 0.0020214 & -0.65 \\
time & -0.0010087 & 0.0015563 & 3.17 \\
secex & $0.0022591^{* * *}$ & 0.000713 & 3.79 \\
secin & $0.006186^{* * *}$ & 0.0007716 & \\
sav & $0.0114381^{* * *}$ & 0.0030159 & \\
\hline \hline observations & 2472485 & & \\
F $(96,2472388)$ & 13003.74 & & \\
prob $>$ F & 0.0000 & & \\
adj. R2 & 0.5144 & & \\
root MSE & 371.69 & & \\
\hline$* * *$ denotes significance at 1\%-level. & & \\
$* *$ denotes significance at $5 \%$-level. & & \\
$*$ denotes significance at 10\%-level. & & \\
\hline
\end{tabular}

Most of the portfolio variables have a significant influence on individual profit contributions. The only variables turning out to be insignificant are income, time deposits and the customers' sex. ${ }^{12}$ All remaining variables turn out to have a highly significant

\footnotetext{
${ }^{11}$ For the sake of clarity, we omit the coefficients of the age-dummies in this table and discuss them later.

12 Since a customer's gender seems not to play a significant role for profit contributions, we make no attempt at distinguishing between male and female customers in the following.
} 


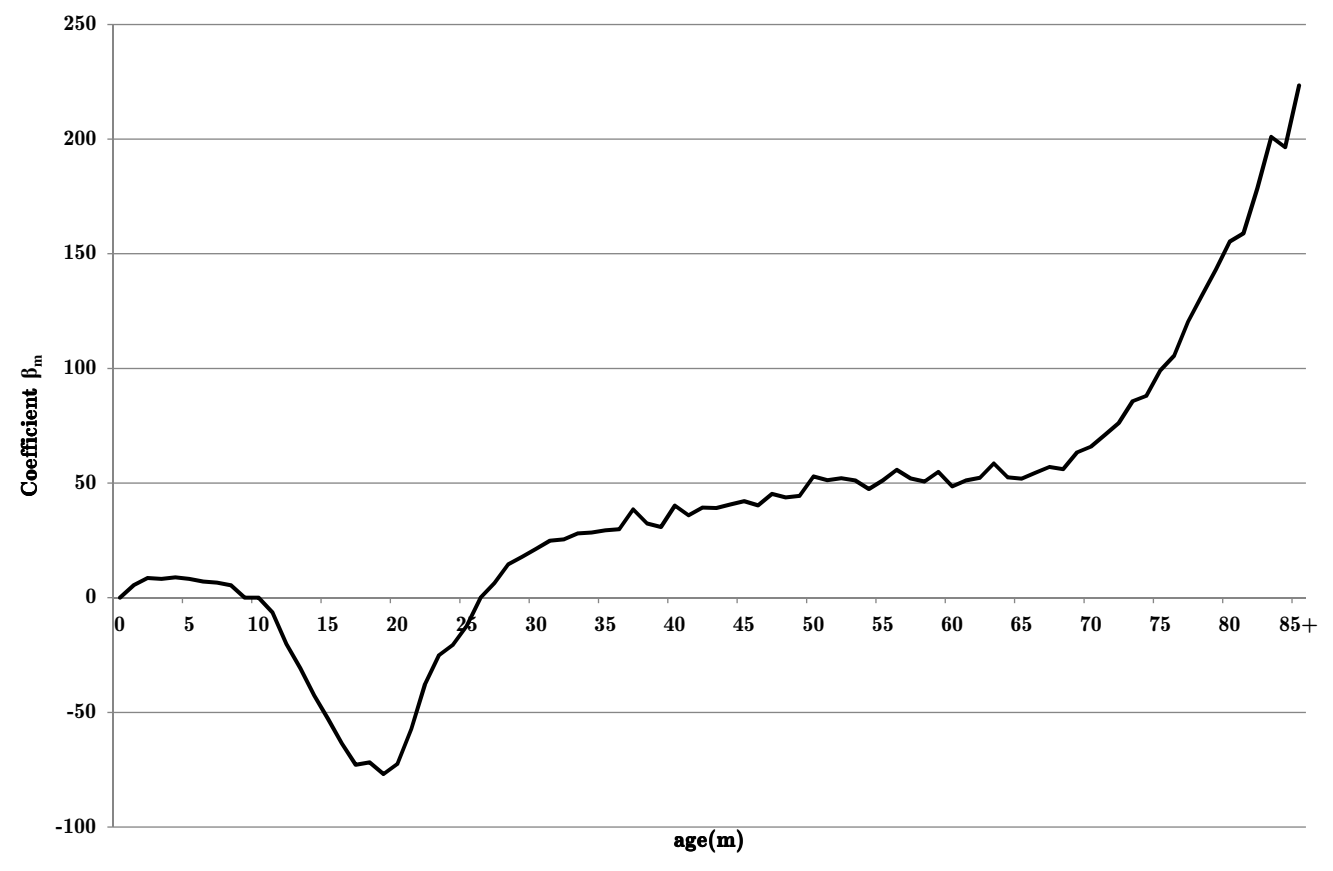

Figure 3. Estimated coefficients of age dummies

and positive effect on individual profit contributions. Altogether, the regressors explain roughly $50 \%$ of the observed variation in profit contributions.

Somewhat surprisingly, the age dummies also turn out to be significantly different from zero (see figure 3). Thus, even after controlling for the age-specific portfolio effects, a customer's age seems to play an important role for the profit contribution. While the age dummies are close to zero until the age of 10, they become negative for ages 11 to 25 . For ages between 25 and 65, age dummies are positive and slightly growing. Beyond the age of 65 , the coefficients are steeply increasing. The maximum is reached at age class $85+$. Controlling for all other factors, a bank earns an extra $€ 223$ from a customer aged 85 or older. ${ }^{13}$

The savings banks invest in the bank-customer relationship in early years. During these years they are willing to offer better conditions and even to make temporary losses. In the age classes above 25 years, i.e. the age where most bank customers have finished

\footnotetext{
13 The reference group are customers aged 0-1. All coefficients except $\beta_{9}, \beta_{10}$ and $\beta_{26}$ exhibit a significance level of $10 \%$ or less. For the age classes 9 , 10, and 26 we have to assume a coefficient of zero.
} 
education, savings banks start to make use of the evolved bank-customer relationship. Elderly customers, i.e. customers in age classes above 65 years, generate excessive profit contributions for their banks. These customers are rarely willing to change their bank affiliation. ${ }^{14}$ Moreover, they are often less informed about bank products and alterantive investment opportunities. This room for manoeuvre is clearly utilized by savings banks.

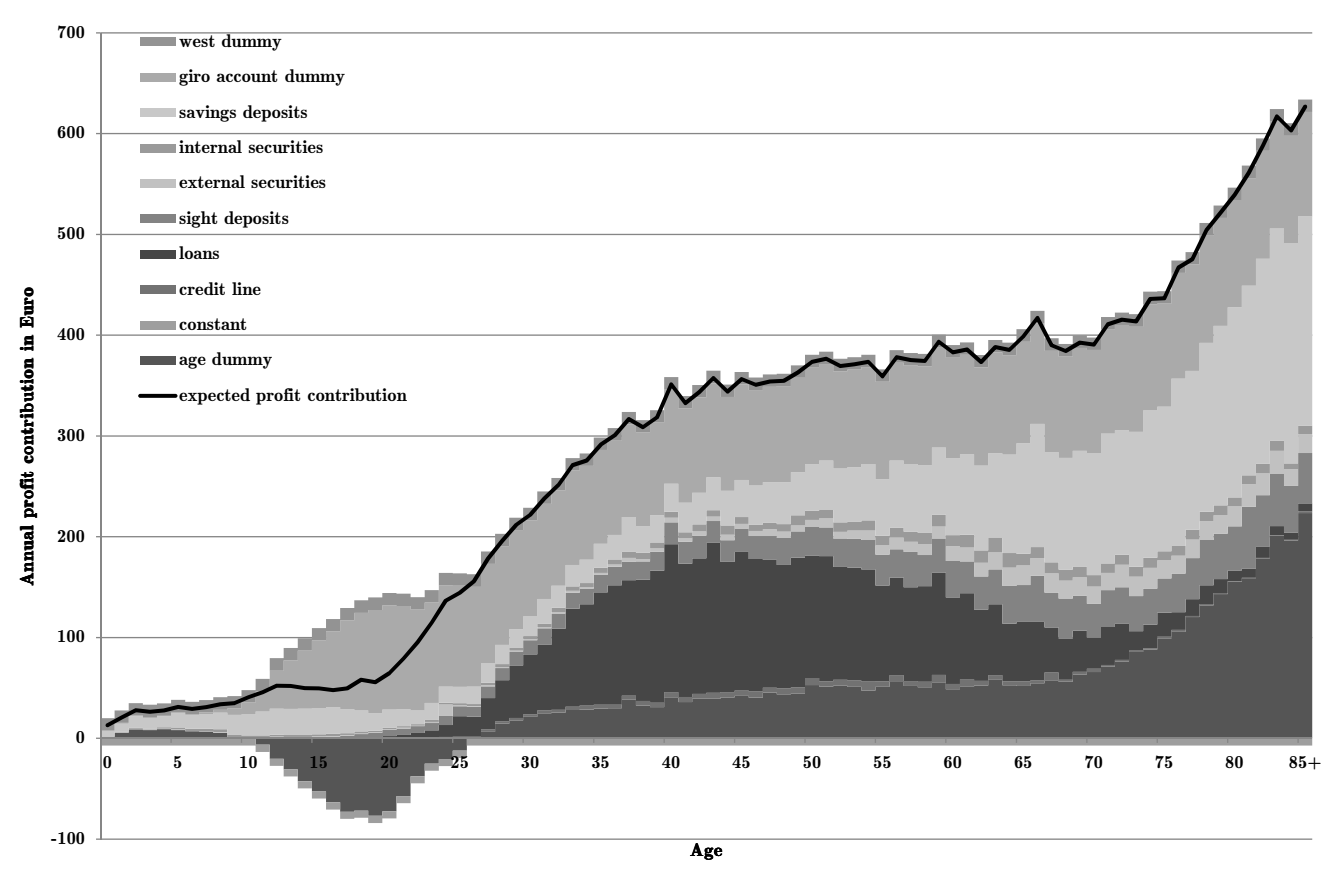

Figure 4. Composition of expected profit contributions per age class in western Germany

Figures 4 and 5 show the composition of the expected profit contributions according to age classes for western and eastern Germany, respectively. Some remarks on the composition of profits are in place. Firstly, giro accounts contribute considerably to profits in all age classes except for the very young customers. Secondly, the importance of savings accounts for bank profits rises with a customer's age to reach a share of roughly one third among the elderly customers. Thirdly, loans contribute perceptibly to the profit contributions only in the age classes between the early thirties and the late sixties. Finally, the age dummies explain a considerable fraction of profit contributions. Among the elderly, this fraction is roughly one third.

\footnotetext{
14 This lock-in phenomenon may be due to switching costs, see e.g. Kim et al. (2003). For a European perspective and analysis of customer mobility in retail banking, see EU-Commission (2007).
} 


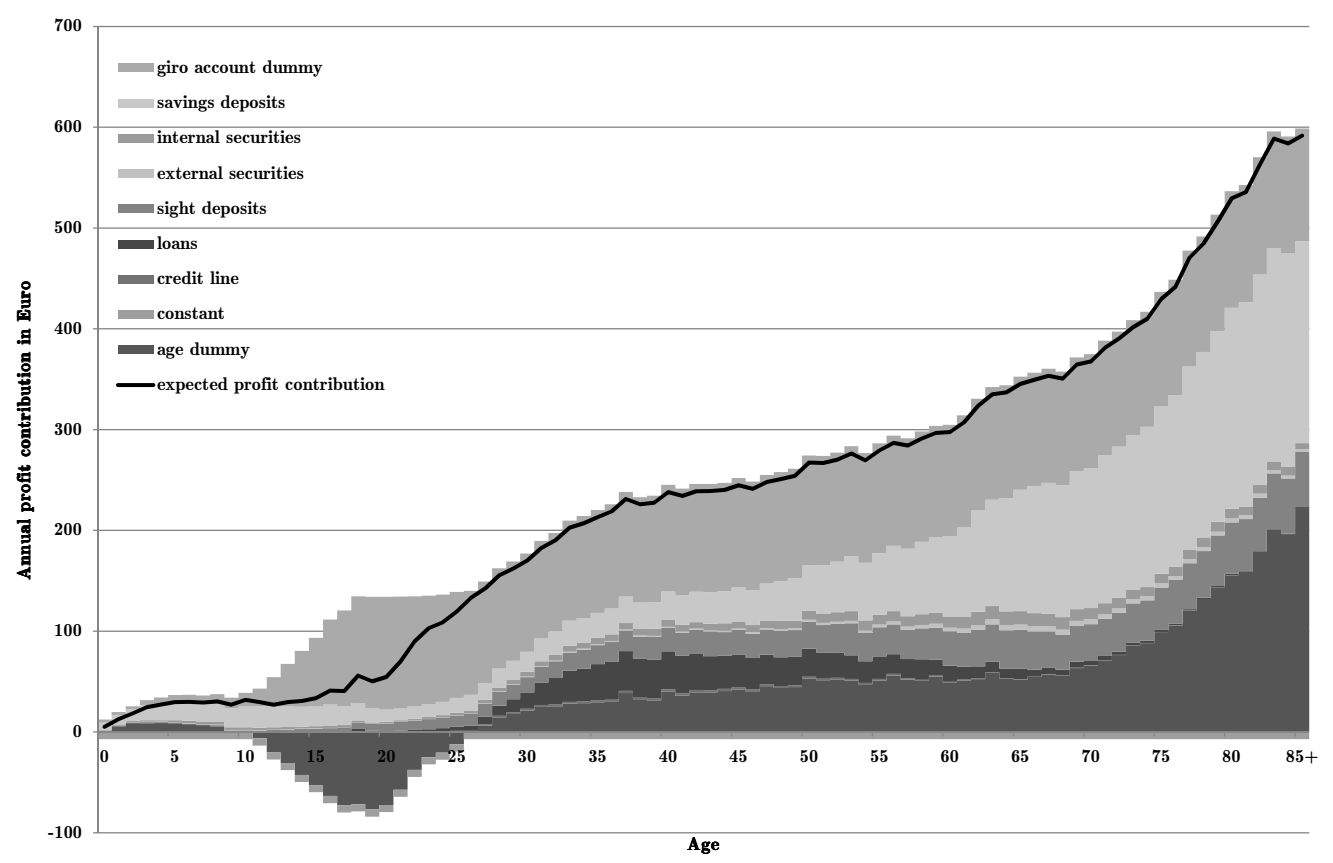

Figure 5. Composition of expected profit contributions per age class in eastern Germany

There are little differences in the composition of profit contributions between western and eastern Germany. However, noteable differences in the level of profit contributions exist between the two regions. From age 25 up to 70, western German customers turn out to be much more profitable than their eastern German counterparts. A customer at the age of 40 generates profits of $€ 238$ in eastern Germany and $€ 351$ in western Germany. This is particularly due to the higher profits from loans in western Germany with $€ 147$ compared to only $€ 37$ in eastern Germany.

\subsection{Market exploitation And PROJeCted Customer DEMOGRAPHiCs}

In the next step, we develop a projection for the customer base of savings banks up to 2025. Figure 6 shows the current market exploitation of savings banks according to age groups. Market exploitation is defined as the ratio of bank customers and population living in a given region. Since savings banks primarily operate in their home regions, the market exploitation rate is a useful measure of market shares for our purposes. 


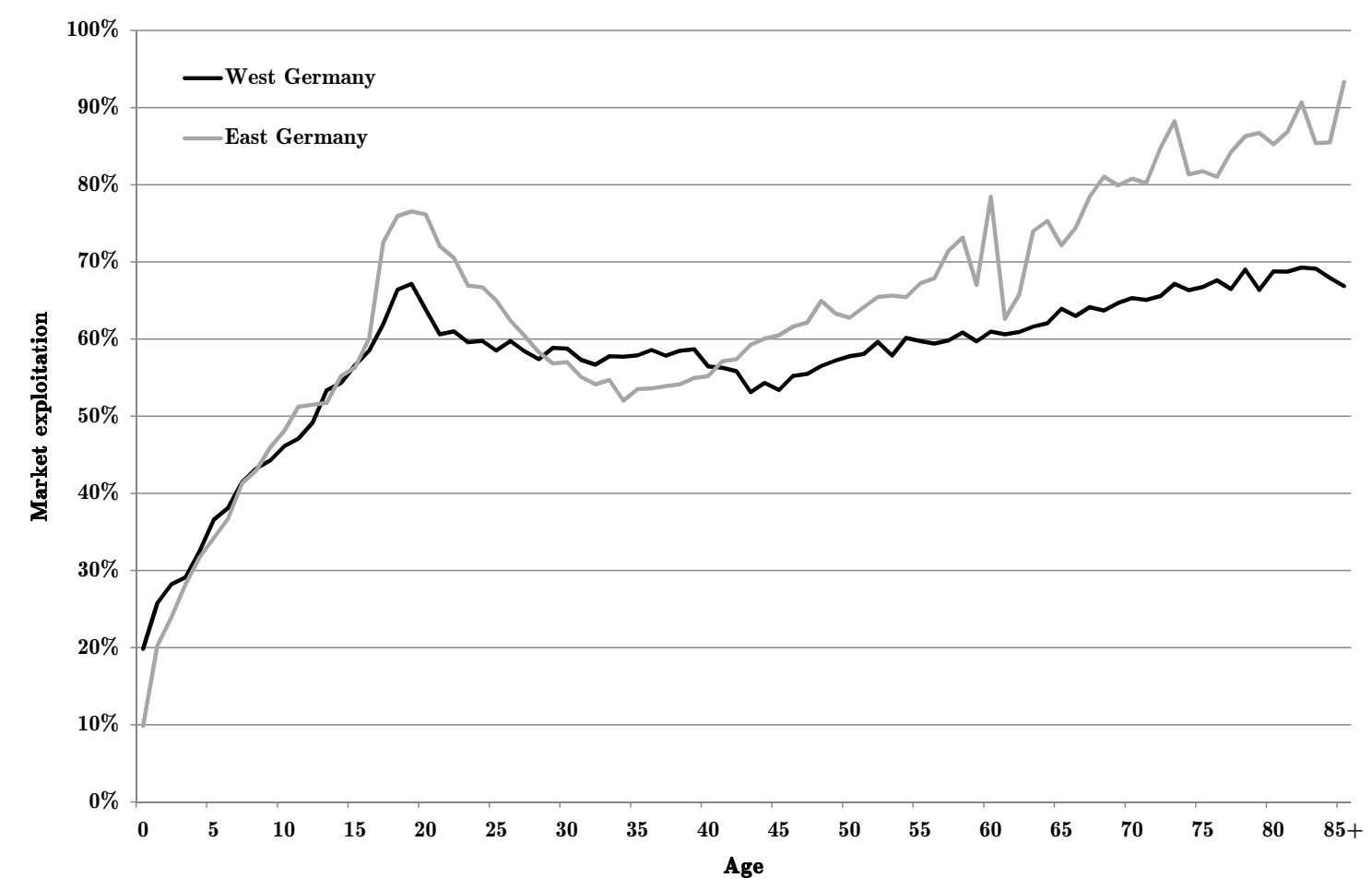

Figure 6. Savings banks' market exploitations in eastern and western Germany

Market exploitation rates somewhat differ between eastern and western Germany. While market exploitation rates are quite similar for the age classes below 40 years, eastern German savings banks have a significantly higher market exploitation among elderly customers. This high market share is an artefact of German history. After world war II, banks in eastern Germany were nationalized. In contrast to various private banks, the savings banks in eastern Germany were not closed but became part of the banking system of the German Democratic Republic (GDR). Throughout GDR times, the savings banks were responsible for all bank transactions among private customers. After German reunification, the savings banks started to operate again in the same manner as their western German counterparts. However, since most eastern Germans had accounts with savings banks, these banks still have abnormally high market exploitation rates, which will only gradually decline in the course of time. 
To obtain a projection for the customer base of German savings banks in a certain year $t$, we multiply the projected market share $m s_{t}^{r, a}$ in region $r$ and age-class $a$ by the population pop $_{t}^{r, a}$ in the same region, age class and year:

$$
\mathrm{cus}_{t}^{r, a}=m s_{t}^{r, a} \cdot \operatorname{pop}_{t}^{r, a} .
$$

For isolating the pure demographic effect, we assume that the market exploitation rates as depicted in figure 6 remain constant over the whole projection horizon. We refer to this "pure demography" scenario in the following as scenario I.

As market exploitation rates are significantly increasing in the age classes above 40, the impact of demographic shrinkage is somewhat smoothed. Although Germany is expected to loose $1.8 \%$ of its population over the projection horizon, the customer base would remain almost unaffected $(-0.2 \%)$, when current market exploitation rates are kept constant. In eastern Germany, market exploitation among the elderly is much bigger but population losses are also larger. Overall, the eastern German customer base will shrink by $9.8 \%$ up to 2025 .

In figure 7 we show the change in the projected customer base of German savings banks until 2025.

\subsection{Projection of BANK PROFits}

We are now able to project the development of bank profits. First, we calculate the portfolio of a representative customer for every single age class. As table II reveals, portfolio characteristics somewhat differ between eastern and western Germany. We therefore construct the portfolios of the representative customers for each age class for eastern and western Germany separately. In a second step, we calculate the profit contributions of the representative customers using the coefficients estimated in section 4.1. Finally, we multiply these profit contributions with the number of projected bank customers and add up for all age classes. This yields a projection of the aggregate profits of savings banks in every single NUTS II region. Summing up over all regions delivers the results displayed in figure 8 . 


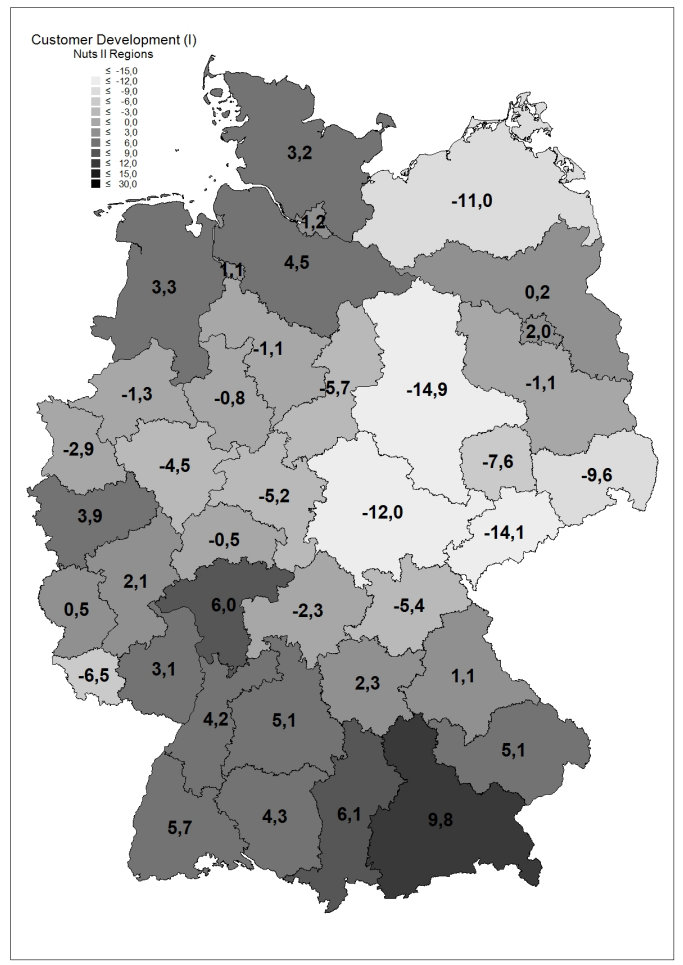

Figure 7. Projected customer development in German NUTS II regions (scenario I), 2006-2025

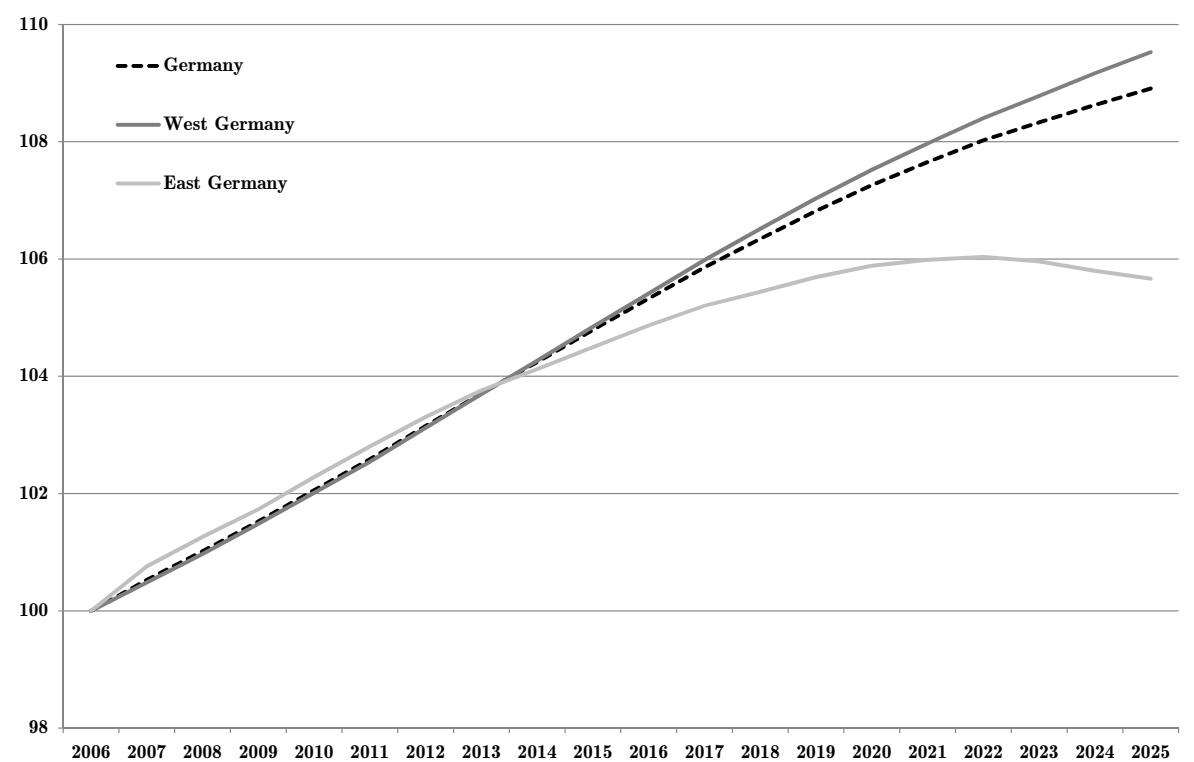

Figure 8. Projected development of profit contributions of German savings banks (scenario I), 2006-2025 


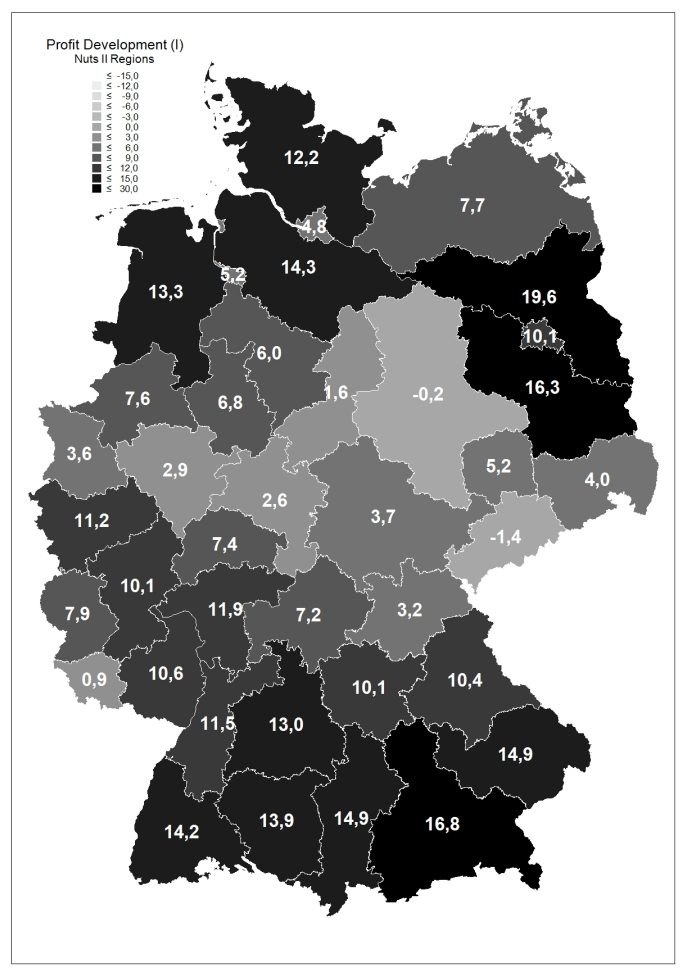

Figure 9. Projected development of profit contributions in German NUTS II regions (scenario I), 2006-2025

The results of the pure demography scenario I are clearcut: On the aggregate level, retail business of German savings banks will not suffer but even benefit from the expected demographic change. Our projections show an increase in profits of German savings banks of $8.9 \%$. While western German savings banks are likely to experience an even sharper increase in retail profits $(9.5 \%)$, even eastern German savings banks are expected to gain $5.7 \%$ additional profits on the aggregate level.

Basically, our results are driven by two counteracting effects. On the one hand, the customer base decreases making the future of German retail banking less bright. On the other hand, ageing leads to a structural change in the customer base towards age groups with higher market expoitation and more profitable product demands. Obviously, the second effect strongly dominates the first effect in the case of Germany with its quickly ageing population. 
A closer look at the regional patterns as displayed in figure 9 shows that there are huge differences between the German NUTS II regions. With the exception of two regions in eastern Germany, all German regions are expected to increase their profits. However, expected growth rates differ by roughly $20 \%$ among these regions.

\section{Increased banking competition}

While the assumptions made in scenario I are useful to isolate the pure demographic effects, their realism is certainly questionable. This is particularly true for the assumption of constant market exploitation rates of German savings banks. The increasing competition among banks will most likely result in decreasing market shares of savings banks. Especially the enormous market exploitation rates among the elderly will hardly be sustainable.

In general, bank customers' willingness to switch their bank connections is decreasing when getting older. Most bank customers stick to their bank affiliation when reaching the mid-thirties. To obtain a more realistic scenario (we will refer to this scenario in

the following as "scenario II") we assume that subsequent cohorts exhibit the pattern of current market exploitation up to the age of 35. Beyond the age of 35, however, we assume that market exploitation remains constant at the level of the currently 35 year old. This implies that the extremely high market expoitation rates among the elderly gradually decline. The change in market exploitation rates over time is illustrated in figure 10.

When applying this development of market exploitation rates, the customer base projections worsen considerably compared to the case of constant market exploitation rates (scenario I). This is especially true for eastern Germany where the current market exploitation rates are exceptionally high among the elderly. The projected loss of customers in eastern Germany more than doubles from 9.8 to $21.6 \%$ while the effect in western Germany is much less pronounced. Instead of winning $1.9 \%$, savings banks in western German now loose $1.6 \%$ of their customers. Due to the massive decline in the eastern 


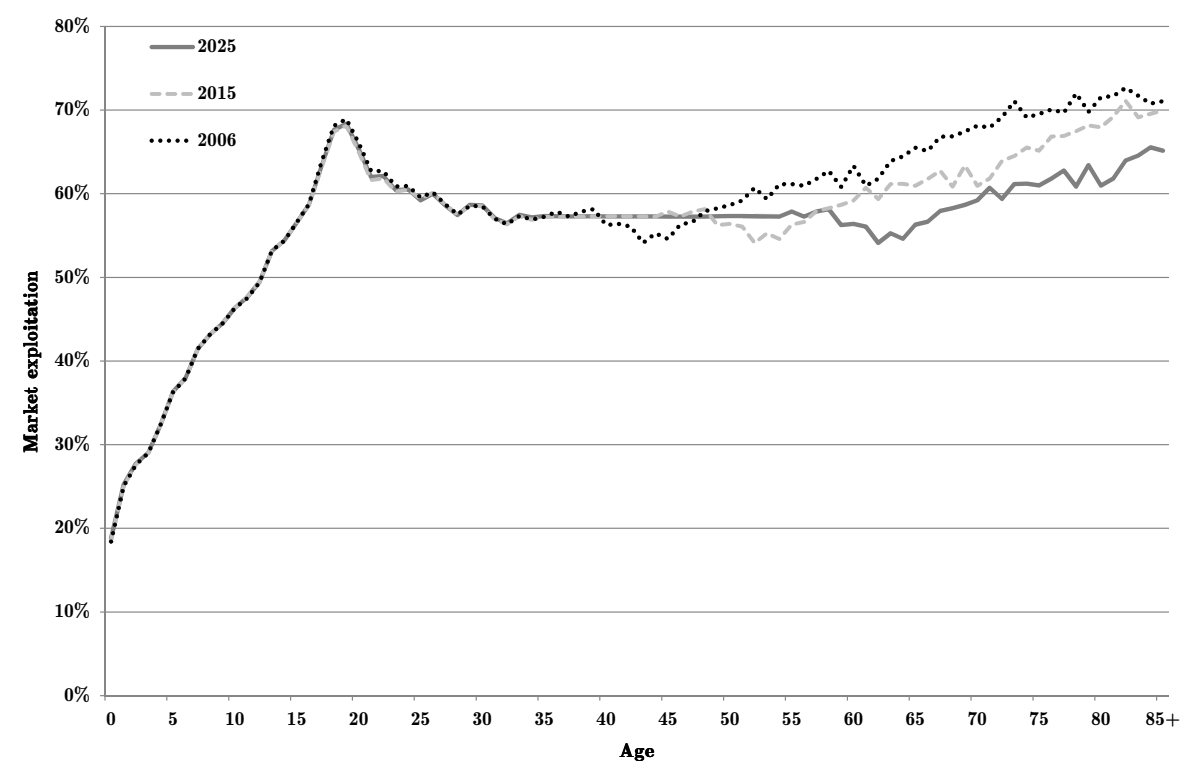

Figure 10. Market exploitation rates under increased banking competition (scenario II), 2006, 2015, 2025

German customer base, German savings banks as a whole are expected to loose $5.2 \%$ of their customers instead of only $0.2 \%$ in scenario I.

Using the same procedure as for scenario I, we again calculate the development of profits. Figure 11 shows the regional results. On the aggregate level, the joint effect of demography and increased banking competition is still slightly positive $(+1.7 \%)$. However, this result is primarily driven by the slightly positive development in western Germany $(+4.3 \%)$. Profit contributions of the eastern German savings banks are expected to decrease by $11.6 \%$ until 2025 in scenario II.

\section{Increased price sensitivity of customers}

In scenarios I and II, we have assumed that the age effects, i.e. the estimated coefficients of the age dummies, remain constant over the whole projection horizon. Obviously, this assumption contributes considerably to the results in scenarios I and II, since the age dummies for age classes above 70 exert a significant influence on overall profits. Even though price sensitivity somewhat decreases over the life cycle, it is far from obvious 


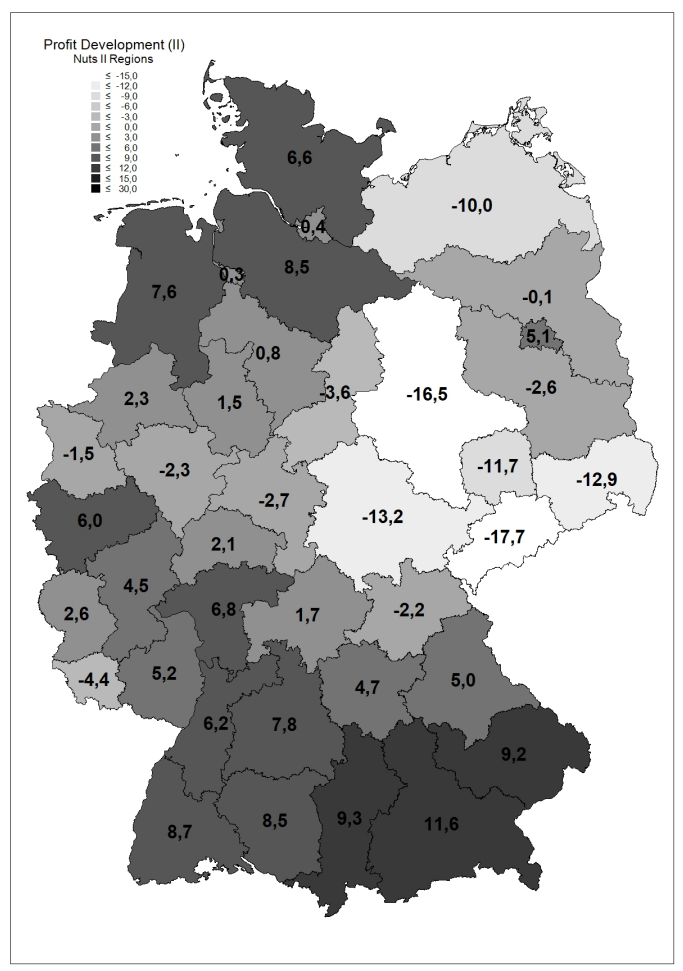

Figure 11. Projected development of profit contributions in German NUTS II regions under increased banking competition (scenario II), 2006-2025

that the exceptionally high profits from elderly customers will also be experienced in the future. Elderly bank customers will be technically more experienced and may be better informed about investment opportunities than their current counterparts. If this line of argument holds true, scenario I and II are likely to be too optimistic.

To account for an increasing price sensitivity, we assume in scenario III that the the age dummies for the age classes above 70 will adjust to the level of the current population at age 70 . The adjustment of age dummies, as illustrated in figure 12, leads to a smoothing of coefficients over time. ${ }^{15}$

In scenario III, profits are expected to decrease by $3.2 \%$. The profits of western German savings banks will remain almost constant (-0.4\%), while their eastern German counterparts loose $18.0 \%$ of their profit contributions over the projection horizon. Using the regional demographic development, we are able to break down the results on the

\footnotetext{
15 The assumptions on market exploitation rates are the same as in scenario II.
} 


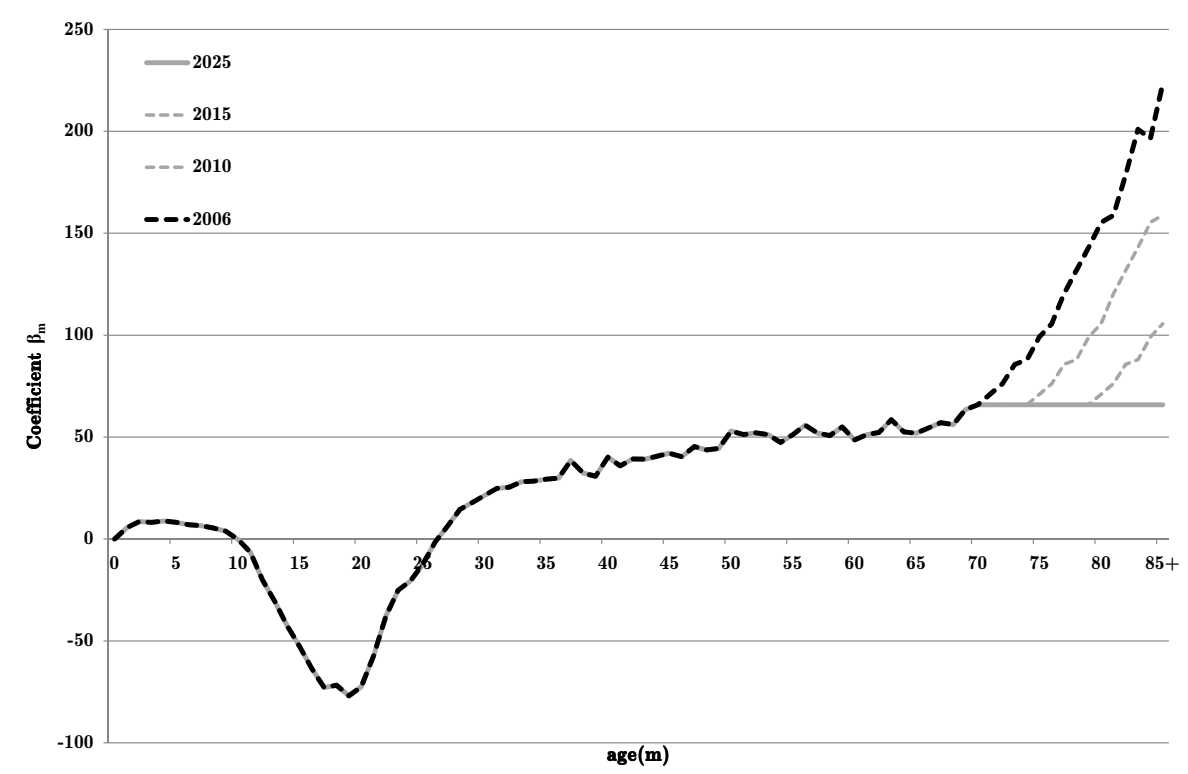

Figure 12. Development of age dummy coefficients under increased price sensitivity of the elderly customers (scenario III), 2006-2025

NUTS II level. Figure 13 shows the regional results. There are huge regional differences with regard to profit developments. Savings banks in demographically stable regions of southern Bavaria and Baden-Wurttemberg are able to gain 3 to $6 \%$ in profits up to 2025 . Within eastern Germany, the savings banks in Saxony, Thuringia and Saxony-Anhalt will suffer the most. The decline in profits reaches from $-18 \%$ to $-24 \%$.

\section{Conclusion}

We have combined a unique data set of bank customers with demographic projections to analyse the impact of demographic change on retail business of savings banks. Table IV summarizes the results with respect to customer bases and profits. The shrinking population puts a significant pressure on the customer base, particularly in eastern Germany. Scenario I, however, shows that ageing provides a strong counterbalancing effect. Even though the customer base declines by almost $10 \%$ in eastern Germany, profits would even increase due to the higher profits generated from elderly customers. The numbers from scenario I are useful for understanding the pure demographic effect. However, they do 


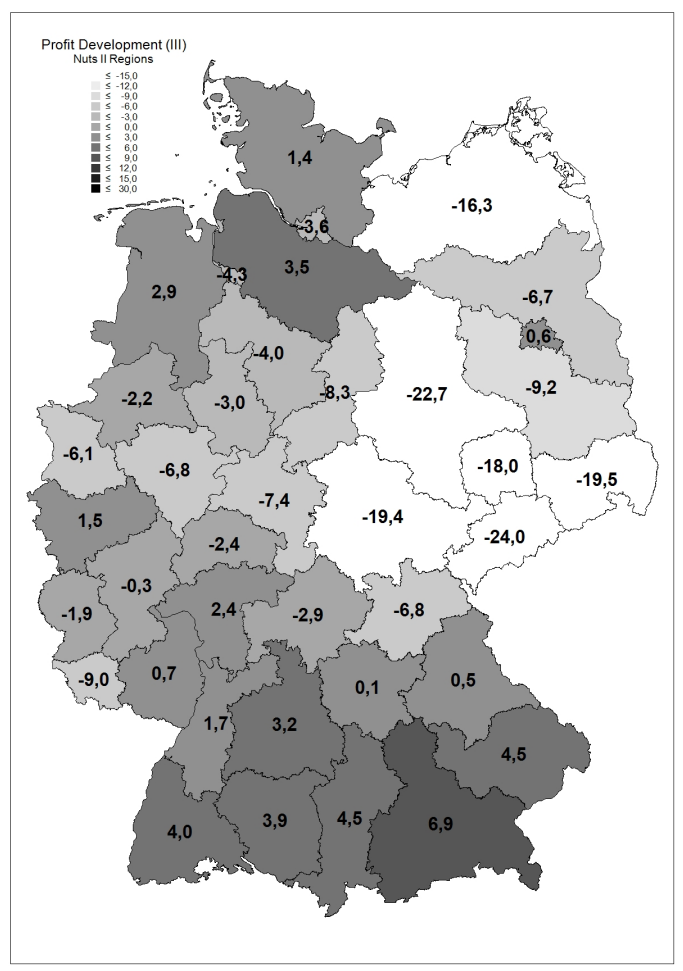

Figure 13. Projected development of profit contributions in German NUTS II regions under increased banking competition and price sensitivity (scenario III), 2006-2025

not provide a realistic scenario for savings banks. Cohort effects will blur the optimistic picture. In the future, savings banks will no longer be able to maintain the high market share among elderly customers and to extract such high rents from this group. In the - what we believe realistic - scenario III, the savings banks in western Germany will experience small declines in the customer base $(-1.6 \%)$ and in profits $(-0.4 \%)$ up to 2025. Eastern German savings banks, however, will loose one fifth of their customer base and they will have to cope with a drop in profits of $18 \%$.

As our analysis is based on a huge data set bank customers, the calculations of the profit contributions are robust and reliable. Nevertheless, there are several ways how our projection could be further improved. Firstly, our data set is fairly representative for eastern Germany (and other economically weaker regions) but does not cover all regional types in western Germany. With additional data from different regions (rural areas, major cities, industrial agglomeration areas,...), we would be able to paint an even 
more detailed picture on the regional impact of demographic change. Secondly, a panel data set could circumvent some of the difficulties in the present study. As our data set is just a cross section from 2006, we had to make interferences from the cross section to the cohort behavior. Panel data would allow to track changes in profit contributions for each individual over time. Finally, our analysis is limited to savings banks. Adding cooperative and private banks, which are also active in retail banking, would allow for an interesting comparison as the structure of profit contributions probably differs between bank types.

Table IV. Summary of projected customer and profit contributions development, 2006-2025

\begin{tabular}{lrrrrrr}
\hline & \multicolumn{3}{c}{ customer base } & \multicolumn{3}{c}{ profits } \\
& $\begin{array}{l}\text { Western } \\
\text { Germany }\end{array}$ & $\begin{array}{c}\text { Eastern } \\
\text { Germany }\end{array}$ & Germany & $\begin{array}{l}\text { Western } \\
\text { Germany }\end{array}$ & $\begin{array}{l}\text { Eastern } \\
\text { Germany }\end{array}$ & Germany \\
\hline & & & & & & \\
scenario I & 1.86 & -9.81 & -0.22 & 9.53 & 5.66 & 8.91 \\
scenario II & -1.59 & -21.60 & -5.15 & 4.25 & -11.61 & 1.71 \\
scenario III & -1.59 & -21.60 & -5.15 & -0.36 & -17.97 & -3.18 \\
& & & & & & -1.83 \\
\hline population & 0.43 & -13.61 & -1.83 & 0.43 & -13.61 & \multicolumn{1}{c}{} \\
\hline
\end{tabular}




\section{References}

Abel, A. B. (2001). Will bequests attenuate the predicted meltdown in stock prices when baby boomers retire? The Review of Economics and Statistics, 83 (4), 589-595.

BBSR - Federal Institute for Research on Building, Urban Affairs and Spatial Development, Germany (2009). Raumordnungsprognose 2025/2050. Berichte Band 29, Bonn.

Boersch-Supan, A., Ludwig, A. and Winter, J. (2002). Ageing and international capital flows. In A. J. Auerbach and H. Herrmann (eds.), Ageing, financial markets and monetary policy, Heidelberg: Springer, 55-83.

Boersch-Supan, A. (2003). Labor market effects of population ageing. Review of Labour Economics and Industrial Relations 17, 5-44.

Borge, L.-E. and Ratts $\emptyset$, J. (2008). Young and old competing for public welfare services. CESifo Working Paper No. 2223.

Brunner, A., Decressin, J.,Hardy, D. and Kudela, B. (2004). Germany's three-pillar banking system: Cross-country perspectives in Europe. IMF Occasional Paper No. 233, Washington, DC.

Casamatta, G., Cremer, H. and Pestieau, P. (2001). Demographic shock and social security: A political economy perspective. International Tax and Public Finance, 8 (4), 417-431.

Cattaneo, M. A. and Wolter, S. C. (2009). Are the elderly a threat to educational expenditures? European Journal of Political Economy 25, 225-236.

Daveri, F. and M. Maliranta (2007). Age, seniority and labour costs: Lessons from the Finnish IT revolution. Economic Policy 49, 117-175.

Demange, G. and Laroque, G. (1999). Social security and demographic shocks. Econometrica, 67 (3), $527-542$.

EU-Commission (2007). Report on the retail banking sector inquiry. Commission Staff Working Document SEC(2007) 106. Accessed September 29, 2009, http://ec.europa.eu/comm/competition/antitrust/others/sector_inquiries/financial_services.

Fehr, H. (2000). Pension reform during the demographic transition. Scandinavian Journal of Economics, $102(3), 419-443$.

Grund, C. and N. Westergard-Nielsen (2008). Age structure of the workforce and firm performance. International Journal of Manpower, forthcoming.

Henschel, B., C. Pohl and M. Thum (2008). Demographic change and regional labour markets: The case of Eastern Germany. CESifo Working Paper No. 2315.

Kim, M., Kliger, D. and Vale, B. (2003). Estimating switching costs: The case of banking. Journal of Financial Intermediation, 12 (1), 25-56.

Krahnen, J. P. and Schmidt, R. H. (2004). The German financial system. Oxford University Press, Oxford.

Krueger, D. and Ludwig, A. (2007). On the consequences of demographic change for rates of returns to capital, and the distribution of wealth and welfare. Journal of Monetary Economics, 54 (1), 49-87.

Lindh, T. and B. Malmberg (1998). Age structure and inflation - A wicksellian interpretation of the OECD data. Journal of Economic Behavior \& Organization 36, 19-37.

Lindh, T. and B. Malmberg (2000). Can age structure forecast inflation trends? Journal of Economics \& Business 52, 31-49.

Miles, D. (1999). Modelling the impact of demographic change upon the economy. Economic Journal 109, 1-36.

Montén, A. and Thum, M. (2009). Ageing municipalities, gerontocracy and fiscal competition. European Journal of Political Economy, forthcoming.

Neuberger, D. and Conrad, A. (2008). Banking in schrumpfenden Regionen - Herausforderung für die Sparkassen. Wissenschaft für die Praxis 65, 18-21.

Poterba, J. (2001). Demographic structure and asset returns. The Review of Economics and Statistics, $83(4), 565-584$.

Poterba, J. (2004). Impact of population ageing on financial markets in developed countries. Economic Review, 89 (4), 43-53.

Skirbekk, V. (2003). Age and individual productivity: A literature survey. Max-Planck-Institute for Demographic Research, Working Paper 28, Rostock.

United Nations (2007). Population Division of the Department of Economic and Social Affairs of the United Nations Secretariat, World Population Prospects: The 2006 revision and World Urbanization Prospects: The 2005 revision. Accessed, May 19, 2008, http://esa.un.org/unpp/ and http://esa.un.org/unup/. 


\section{Appendix}

Table V. Correlation Matrix

\begin{tabular}{lrrrrrrrrr}
\hline & prof & inc & cred & loan & sight & time & secex & secin & sav \\
\hline prof & 1.0000 & & & & & & & & \\
inc & 0.1647 & 1.0000 & & & & & & & \\
cred & 0.1242 & 0.0429 & 1.0000 & & & & & & \\
loan & 0.4421 & 0.0554 & 0.1197 & 1.0000 & & & & & \\
sight & 0.3094 & 0.2863 & 0.0044 & 0.0265 & 1.0000 & & & & \\
time & 0.0591 & 0.0354 & 0.0181 & 0.0180 & 0.2908 & 1.0000 & & & \\
secex & 0.1904 & 0.1199 & 0.0168 & 0.0386 & 0.0907 & 0.0678 & 1.0000 & & \\
secin & 0.1509 & 0.0567 & -0.0025 & 0.0053 & 0.0668 & 0.0331 & 0.0676 & 1.0000 & \\
sav & 0.4534 & 0.0776 & -0.0093 & -0.0169 & 0.1619 & 0.0176 & 0.0405 & 0.0963 & 1.0000 \\
& & & & & & & & & \\
\hline
\end{tabular}

Table VI. Spearman Rank Correlation

\begin{tabular}{lrrrrrrrrr}
\hline & prof & inc & cred & loan & sight & time & secex & secin & sav \\
\hline prof & 1.0000 & & & & & & & & \\
inc & 0.5948 & 1.0000 & & & & & & & \\
cred & 0.0866 & 0.0830 & 1.0000 & & & & & & \\
loan & 0.2597 & 0.1046 & 0.1481 & 1.0000 & & & & & \\
sight & 0.6175 & 0.6486 & -0.2763 & -0.0599 & 1.0000 & & & & \\
time & 0.0791 & 0.0265 & -0.0192 & 0.0044 & 0.0497 & 1.0000 & & & \\
secex & 0.2375 & 0.1470 & -0.0157 & -0.0060 & 0.1986 & 0.0845 & 1.0000 & & \\
secin & 0.1556 & 0.1277 & -0.0400 & 0.0111 & 0.1364 & 0.0096 & 0.1991 & 1.0000 & \\
sav & 0.4322 & 0.1351 & -0.1295 & -0.1066 & 0.2549 & 0.0477 & 0.1710 & 0.1129 & 1.0000 \\
& & & & & & & & & \\
\hline
\end{tabular}




\section{CESifo Working Paper Series}

for full list see www.cesifo-group.org/wp

(address: Poschingerstr. 5, 81679 Munich, Germany, office@cesifo.de)

2849 Margarita Katsimi and Vassilis Sarantides, The Impact of Fiscal Policy on Profits, November 2009

2850 Scott Alan Carson, The Relationship between Stature and Insolation: Evidence from Soldiers and Prisoners, November 2009

2851 Horst Raff and Joachim Wagner, Intra-Industry Adjustment to Import Competition: Theory and Application to the German Clothing Industry, November 2009

2852 Erkki Koskela, Impacts of Labor Taxation with Perfectly and Imperfectly Competitive Labor Markets under Flexible Outsourcing, November 2009

2853 Cletus C. Coughlin and Dennis Novy, Is the International Border Effect Larger than the Domestic Border Effect? Evidence from U.S. Trade, November 2009

2854 Johannes Becker and Clemens Fuest, Source versus Residence Based Taxation with International Mergers and Acquisitions, November 2009

2855 Andreas Hoffmann and Gunther Schnabl, A Vicious Cycle of Manias, Crashes and Asymmetric Policy Responses - An Overinvestment View, November 2009

2856 Xavier Vives, Strategic Supply Function Competition with Private Information, November 2009

2857 M. Hashem Pesaran and Paolo Zaffaroni, Optimality and Diversifiability of Mean Variance and Arbitrage Pricing Portfolios, November 2009

2858 Davide Sala, Philipp J.H. Schröder and Erdal Yalcin, Market Access through Bound Tariffs, November 2009

2859 Ben J. Heijdra and Pim Heijnen, Environmental Policy and the Macroeconomy under Shallow-Lake Dynamics, November 2009

2860 Enrico Spolaore, National Borders, Conflict and Peace, November 2009

2861 Nina Czernich, Oliver Falck, Tobias Kretschmer and Ludger Woessmann, Broadband Infrastructure and Economic Growth, December 2009

2862 Evžen Kočenda and Martin Vojtek, Default Predictors and Credit Scoring Models for Retail Banking, December 2009

2863 Christian Gollier and Martin L. Weitzman, How Should the Distant Future be Discounted when Discount Rates are Uncertain?, December 2009 
2864 Tiberiu Dragu and Mattias Polborn, Terrorism Prevention and Electoral Accountability, December 2009

2865 Torfinn Harding and Beata Smarzynska Javorcik, A Touch of Sophistication: FDI and Unit Values of Exports, December 2009

2866 Matthias Dischinger and Nadine Riedel, There's no Place like Home: The Profitability Gap between Headquarters and their Foreign Subsidiaries, December 2009

2867 Andreas Haufler and Frank Stähler, Tax Competition in a Simple Model with Heterogeneous Firms: How Larger Markets Reduce Profit Taxes, December 2009

2868 Steinar Holden, Do Choices Affect Preferences? Some Doubts and New Evidence, December 2009

2869 Alberto Asquer, On the many Ways Europeanization Matters: The Implementation of the Water Reform in Italy (1994-2006), December 2009

2870 Choudhry Tanveer Shehzad and Jakob De Haan, Financial Reform and Banking Crises, December 2009

2871 Annette Alstadsæter and Hans Henrik Sievertsen, The Consumption Value of Higher Education, December 2009

2872 Chris van Klaveren, Bernard van Praag and Henriette Maassen van den Brink, Collective Labor Supply of Native Dutch and Immigrant Households in the Netherlands, December 2009

2873 Burkhard Heer and Alfred Maußner, Computation of Business-Cycle Models with the Generalized Schur Method, December 2009

2874 Carlo Carraro, Enrica De Cian and Massimo Tavoni, Human Capital Formation and Global Warming Mitigation: Evidence from an Integrated Assessment Model, December 2009

2875 André Grimaud, Gilles Lafforgue and Bertrand Magné, Climate Change Mitigation Options and Directed Technical Change: A Decentralized Equilibrium Analysis, December 2009

2876 Angel de la Fuente, A Mixed Splicing Procedure for Economic Time Series, December 2009

2877 Martin Schlotter, Guido Schwerdt and Ludger Woessmann, Econometric Methods for Causal Evaluation of Education Policies and Practices: A Non-Technical Guide, December 2009

2878 Mathias Dolls, Clemens Fuest and Andreas Peichl, Automatic Stabilizers and Economic Crisis: US vs. Europe, December 2009 
2879 Tom Karkinsky and Nadine Riedel, Corporate Taxation and the Choice of Patent Location within Multinational Firms, December 2009

2880 Kai A. Konrad, Florian Morath and Wieland Müller, Taxation and Market Power, December 2009

2881 Marko Koethenbuerger and Michael Stimmelmayr, Corporate Taxation and Corporate Governance, December 2009

2882 Gebhard Kirchgässner, The Lost Popularity Function: Are Unemployment and Inflation no longer Relevant for the Behaviour of Germany Voters?, December 2009

2883 Marianna Belloc and Ugo Pagano, Politics-Business Interaction Paths, December 2009

2884 Wolfgang Buchholz, Richard Cornes and Dirk Rübbelke, Existence and Warr Neutrality for Matching Equilibria in a Public Good Economy: An Aggregative Game Approach, December 2009

2885 Charles A.E. Goodhart, Carolina Osorio and Dimitrios P. Tsomocos, Analysis of Monetary Policy and Financial Stability: A New Paradigm, December 2009

2886 Thomas Aronsson and Erkki Koskela, Outsourcing, Public Input Provision and Policy Cooperation, December 2009

2887 Andreas Ortmann, "The Way in which an Experiment is Conducted is Unbelievably Important": On the Experimentation Practices of Economists and Psychologists, December 2009

2888 Andreas Irmen, Population Aging and the Direction of Technical Change, December 2009

2889 Wolf-Heimo Grieben and Fuat Şener, Labor Unions, Globalization, and Mercantilism, December 2009

2890 Conny Wunsch, Optimal Use of Labor Market Policies: The Role of Job Search Assistance, December 2009

2891 Claudia Buch, Cathérine Tahmee Koch and Michael Kötter, Margins of International Banking: Is there a Productivity Pecking Order in Banking, too?, December 2009

2892 Shafik Hebous and Alfons J. Weichenrieder, Debt Financing and Sharp Currency Depreciations: Wholly vs. Partially Owned Multinational Affiliates, December 2009

2893 Johannes Binswanger and Daniel Schunk, What is an Adequate Standard of Living during Retirement?, December 2009

2894 Armin Falk and James J. Heckman, Lab Experiments are a Major Source of Knowledge in the Social Sciences, December 2009 
2895 Hartmut Egger and Daniel Etzel, The Impact of Trade on Employment, Welfare, and Income Distribution in Unionized General Oligopolistic Equilibrium, December 2009

2896 Julian Rauchdobler, Rupert Sausgruber and Jean-Robert Tyran, Voting on Thresholds for Public Goods: Experimental Evidence, December 2009

2897 Michael McBride and Stergios Skaperdas, Conflict, Settlement, and the Shadow of the Future, December 2009

2898 Ben J. Heijdra and Laurie S. M. Reijnders, Economic Growth and Longevity Risk with Adverse Selection, December 2009

2899 Johannes Becker, Taxation of Foreign Profits with Heterogeneous Multinational Firms, December 2009

2900 Douglas Gale and Piero Gottardi, Illiquidity and Under-Valuation of Firms, December 2009

2901 Donatella Gatti, Christophe Rault and Anne-Gaël Vaubourg, Unemployment and Finance: How do Financial and Labour Market Factors Interact?, December 2009

2902 Arno Riedl, Behavioral and Experimental Economics Can Inform Public Policy: Some Thoughts, December 2009

2903 Wilhelm K. Kohler and Marcel Smolka, Global Sourcing Decisions and Firm Productivity: Evidence from Spain, December 2009

2904 Marcel Gérard and Fernando M. M. Ruiz, Corporate Taxation and the Impact of Governance, Political and Economic Factors, December 2009

2905 Mikael Priks, The Effect of Surveillance Cameras on Crime: Evidence from the Stockholm Subway, December 2009

2906 Xavier Vives, Asset Auctions, Information, and Liquidity, January 2010

2907 Edwin van der Werf, Unilateral Climate Policy, Asymmetric Backstop Adoption, and Carbon Leakage in a Two-Region Hotelling Model, January 2010

2908 Margarita Katsimi and Vassilis Sarantides, Do Elections Affect the Composition of Fiscal Policy?, January 2010

2909 Rolf Golombek, Mads Greaker and Michael Hoel, Climate Policy without Commitment, January 2010

2910 Sascha O. Becker and Ludger Woessmann, The Effect of Protestantism on Education before the Industrialization: Evidence from 1816 Prussia, January 2010

2911 Michael Berlemann, Marco Oestmann and Marcel Thum, Demographic Change and Bank Profitability. Empirical Evidence from German Savings Banks, January 2010 